\title{
Status of the avifauna of San Rafael National Park, one of the last large fragments of Atlantic Forest in Paraguay
}

\author{
ALBERTO ESQUIVEL M., MYRIAM C. VELÁZQUEZ, ALEJANDRO BODRATI, \\ ROSENDO FRAGA, HUGO DEL CASTILLO, JUAN KLAVINS, ROBERT P. CLAY, \\ ALBERTO MADROÑO and SALVADOR J. PERIS
}

\section{Summary}

We provide new information on all birds known from San Rafael National Park, Paraguay. Ornithological records from the period 1997 to 2006 have been reviewed, adding 112 new species to the reserve's avifauna. We provide data on the presence of 405 species in seven basic habitats types, and on their relative abundance. Biogeographically, San Rafael has a mixed avifauna, consisting of 70 Atlantic Forest endemic species, two Mesopotamian Grassland endemics, and many with a wider distribution in South America. At least 12 species are threatened and 16 nearthreatened, including important populations of Dryocopus galeatus, Platyrinchus leucoryphus, Alectrurus tricolor and Xanthopsar flavus. We provide brief comments on records of these 28 species within the study site. The avifauna of the reserve is one the most important in Paraguay, due to its high diversity and endemism. At the same time, it is under great threat and its viability is at risk unless urgent actions are taken. Fragmentation of the Atlantic Forest in Paraguay has left the San Rafael block almost totally isolated from other forests. The degradation of its forests through selective logging and clearance for agriculture still has severe impacts, as do hunting and frequent fires in grasslands and forests. Unfortunately, the legal situation of the National Park is extremely precarious, creating great uncertainty and problems for its conservation.

\section{Resumen}

Aqui relatamos nuevas informaciones sobre todas las aves conocidas hasta el presente dentro del Parque Nacional San Rafael. Se han revisado registros ornitológicos comprendidos entre los años 1997 y 2006, que han permitido añadir 112 especies nuevas para la reserva. De esta manera, San Rafael tiene un total de 405 especies registradas. Para cada una de ellas se facilitan datos que documentan su presencia en siete tipos de hábitats básicos diferenciados, y de su abundancia relativa. Biogeográficamente, la avifauna de San Rafael es una mezcla que está compuesta por 70 especies endémicas del Bosque Atlántico, dos endémicas de los Pastizales de la Mesopotamia, y el resto, son de distribución más amplia en Sudamérica. Al menos, 12 especies están amenazadas y 16 casi-amenazadas, incluyendo poblaciones importantes de Dryocopus galeatus, Platyrinchus leucoryphus, Alectrurus tricolor y Xanthopsar flavus. De éstas 28 especies, se proporcionan comentarios breves sobre sus registros en el área de estudio. La avifauna de la reserva resulta una de las más importantes dentro del Paraguay, tanto por su mayor diversidad y presencia de endemismos, como por ser una de las áreas con alto potencial para mantener la biodiversidad, al tiempo que se encuentra sometida a fuertes amenazas que ponen en peligro su viabilidad en caso de no tomarse medidas urgentes. La alta fragmentación del Bosque Atlántico dentro del 
Paraguay, ha dejado al bloque de San Rafael prácticamente aislado de otros bosques. La degradación de sus bosques por tala selectiva y desmonte para agricultura son aún grandes impactos dentro de sus límites, así como la caza furtiva y la quema frecuente inducida de pastizales y bosques. Desafortunadamente, la situación legal del Parque Nacional es extremadamente precaria, generando así gran incertidumbre y dificultad para su conservación.

\section{Introduction}

Paraguay $\left(406,000 \mathrm{~km}^{2}\right)$, although land-locked, has a remarkable species richness, resulting from its location at the crossroads of a number of globally important biomes. Atlantic Forest, Cerrado, Mesopotamian Grasslands, the Gran Chaco and the Pantanal all converge within the country. The avifauna of Paraguay was recently one of the least known of any country in South America (Lowen et al. 1995). A complete review of the birds of Paraguay, detailing the status and distribution of 645 species, was finally published in 1995 (Hayes 1995). Since then, 685 species have been documented within the country by Guyra Paraguay (2004), and a more recent atlas of the birds of Paraguay maps the distribution of 707 species (Guyra Paraguay 2005). To date, most ornithological studies in Paraguay have focused on the Atlantic Forest (Lowen et al. 1995, 1996a, b; Madroño et al. 1995, 1997a, b), though much information remains to be published on the Atlantic Forest as well as on other biomes.

The Atlantic Forest of south-eastern Brazil, north-eastern Argentina and eastern Paraguay is recognized as a hotspot for biodiversity, due to its tremendous diversity and the numerous endemic species (Mittermeier et al. 1999, Myers et al. 2000). Of the various biomes in Paraguay, the Atlantic Forest has suffered the most habitat loss and degradation, with forest loss rates at their greatest in recent years (Cartes 2003). Originally covering $>88,000 \mathrm{~km}^{2}$ in the eastern region of the country, by 1997 only $20,800 \mathrm{~km}^{2}(\sim 23 \%)$ of forest remained (Barboza et al. 1997). The remaining forest is also degraded and fragmented (Barboza et al. 1997), with only $1,580 \mathrm{~km}^{2}(<2 \%$ of the original) effectively protected (Cartes 2000$)$.

Within the Paraguayan Atlantic Forest, one of the four key areas for threatened and restricted-range birds is San Rafael National Park (SRNP; Stattersfield et al. 1998). When San Rafael was first declared as an 'Area Reserved for a National Park' in 1992, the reserve encompassed $780 \mathrm{~km}^{2}$ (DPNVS 1993). As a result of conflicts between National Park status and the land tenure situation (all of San Rafael is privately owned) the management category of the area was changed in 2002 to that of 'Managed Resources Reserve' (equivalent to a category VI protected area in the IUCN classification). This was then reversed in 2005. Despite its status as a protected area, an average of $9.8 \mathrm{~km}^{2} /$ year of forest was cleared during the period 1989-2002, and more than $18 \mathrm{~km}^{2}$ of grasslands were converted into agricultural land and cattle pastures during the same period. Consequently, at present more than $22 \%$ of the original area of SRNP has been severely modified (A. Parra et al. unpubl. report).

The first inventory of the birds of SRNP included 215 species (Lowen et al. 1996b). In subsequent surveys, the total number of species increased to 294 (Madroño et al. 1997a). In 1997, one of us (A.M.) studied the birds in San Rafael during April, June and November, with a total of 15 days of fieldwork. In October 2000, a team of ornithologists from the University of Kansas (K. Zyskowski et al. unpubl. data) visited the reserve for 18 days. During 2000-2003, more extensive surveys were undertaken by a team (including M.C.V., A.B., A.E., H.D.C., J.K., R.F., R.P.C., E. Coconier and S. Villanueva) from Guyra Paraguay, a Paraguayan non-profit NGO. Another of us (A.E.M.) carried out research in the reserve during December 2003, August to November 2004, October and December 2005, and January 2006. During this period, M. Navarro, a forest guard of the local NGO Pro Cosara, also contributed with observations and new additions to the avifauna of San Rafael. Finally, during February-March 2006, P. Smith led a volunteer project conducting surveys in the south-east of the reserve. As a consequence of these recent and intensive efforts, 405 species of bird are now known from 
San Rafael, including 12 threatened and 16 near-threatened species (BirdLife International 2006).

Here, we provide updated information on the status and abundance of the birds of San Rafael, most notably for the globally threatened species. We also summarize habitat preferences and distribution data within the area. It is hoped that this review will help draw attention to the rich and threatened avian diversity found within SRNP, and catalyse renewed efforts to consolidate the area as an effectively protected reserve.

\section{Methods and study area}

\section{Location, topography and climate}

San Rafael National Park (SRNP; $26^{\circ} 25^{\prime} \mathrm{S}, 55^{\circ} 40^{\prime} \mathrm{W}$ ) is located in the upper watershed of the Tebicuary river (a major tributary of the Paraguay river), in the San Rafael hill range in Itapúa and Caazapá Departments (Figure 1). Including $748 \mathrm{~km}^{2}$ that encompass Atlantic Forest and Mesopotamian Grasslands ecosystems, elevations are 100-500 m. San Rafael straddles a transitional area of the Atlantic Forest, where tall, humid forests of the Paraná river watershed give way to lower and drier forests in the Paraguay river watershed. Consequently, CDC (1990) considered SRNP to lie on the border between the Alto Paraná and Selva Central ecoregions, while Hayes (1995) placed it on the border between his Central Paraguay and Alto Paraná ornithogeographic region. Guyra Paraguay (2004) recognized the transitional nature of San Rafael, but considered its avifauna to be more typical of the Alto Paraná ornithogeographic region and thus treated San Rafael as the limit of that region.

Rain falls throughout the year with a yearly average of 2,100 mm, and is greatest between October and February. Temperature is variable with the hottest period being October to April (average $23.8^{\circ} \mathrm{C}$ ) and the coldest from May to September $\left(17{ }^{\circ} \mathrm{C}\right.$; Figure 2).

\section{Description of the vegetation}

San Rafael contains seven main habitat types: forest, forest edge, scrub, grassland, wetland, water and agricultural.

\section{Forest}

Forest is the dominant vegetation type, occupying approximately $80 \%$ of the reserve. A variety of forest habitats exist: primary forest, with trees $>20 \mathrm{~m}$ high, closed canopy and open understorey; degraded forest, with trees $15-19 \mathrm{~m}$, open canopy and dense understorey with thin bamboo (Chusquea ramosissima); gallery forest, with thick bamboo (Guadua sp.), and natural forest islands. The most common canopy tree species are Nectandra megapotamica, Chrysophyllum gonocarpum, Cabralea canjerana, Ficus enormis, Balfourodendron riedelianum and Bastardiopsis densiflora. The most common understorey plant species are Actinostemon concolor, Sorocea bonplandii, Piper sp., Inga marginata and Trichilia catigua. Lianas (Bignoniaceae, Apocynaceae, Dilleniaceae), epiphytes (Orchidaceae, Bromeliaceae, Araceae) and ferns (Pteridophyta) are common and often abundant. For a more detailed botanical description of a forest plot at Parabel $\left(26^{\circ} 20^{\prime} \mathrm{S} 55^{\circ} 32^{\prime} \mathrm{W}\right)$, north-east SRNP see Keel et al. (1993).

Forest edge and scrub

We considered forest edge to extend $20 \mathrm{~m}$ within the forest from the boundary with other nonforest vegetation types. Scrub, comprising bushes and small isolated trees, occurs at the edge between forests and grasslands. Secondary succession within the forest was also considered 

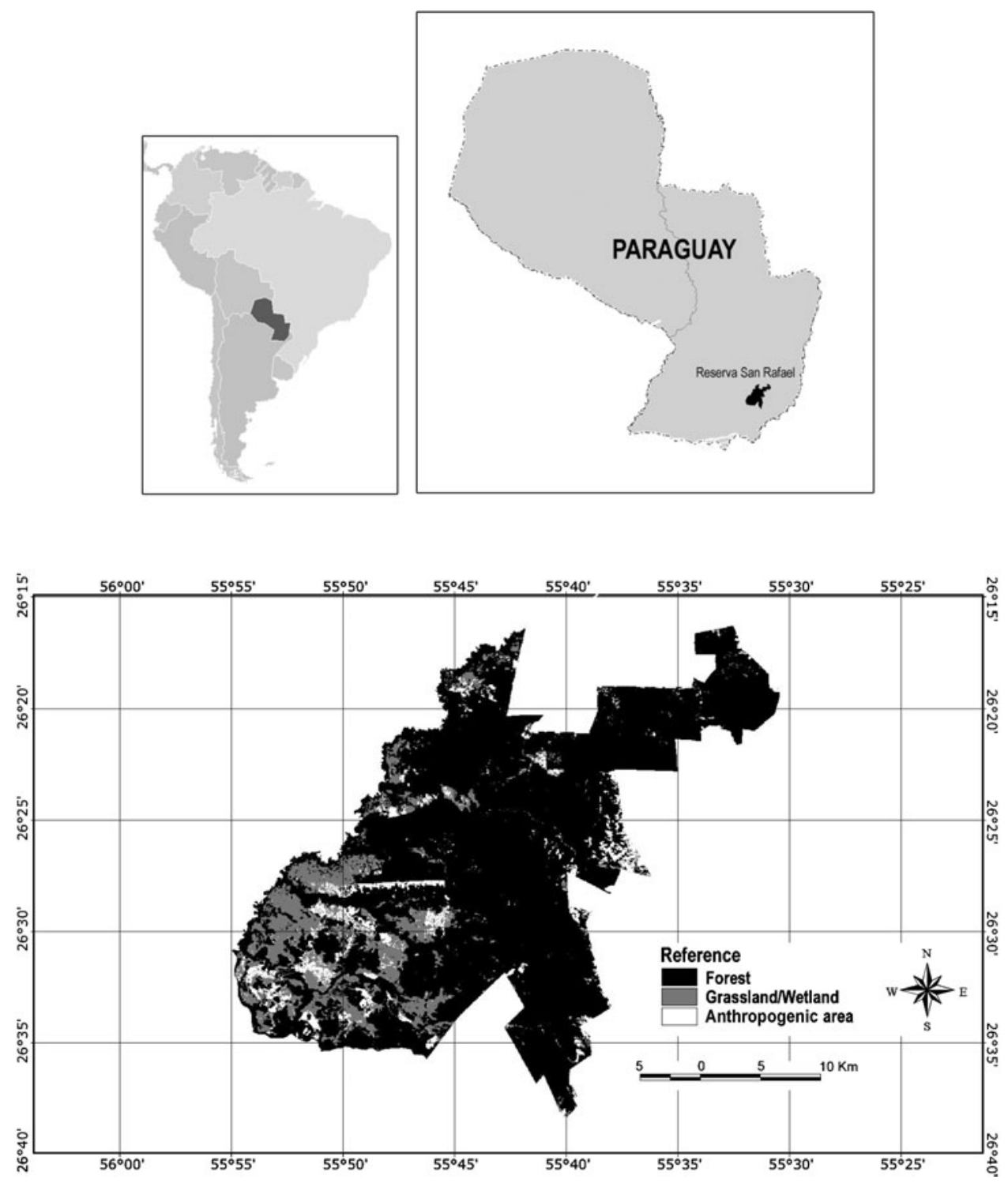

Figure 1. Location of San Rafael National Park in south-east Paraguay. Vegetation cover is divided into three main classes - forest, grassland/wetland and anthropogenic areas - classified from a LandSat image of 2 January 2004 (Guyra Paraguay, unpubl. data).

scrub. The most common plant species are pioneers, such as Cecropia pachystachya, Baccharis punctulata and Solanum granuloso-leprosum. Grassland fires commonly reach the scrub and edge vegetation, and some plants are fire-adapted.

\section{Grassland/Wetland}

Both grassland and wetland occur in the south-west of the reserve, covering approximately $8 \%$ of its area. Topography is rolling and the soil is sandy-clay. Grasses (Poaceae) dominate the 


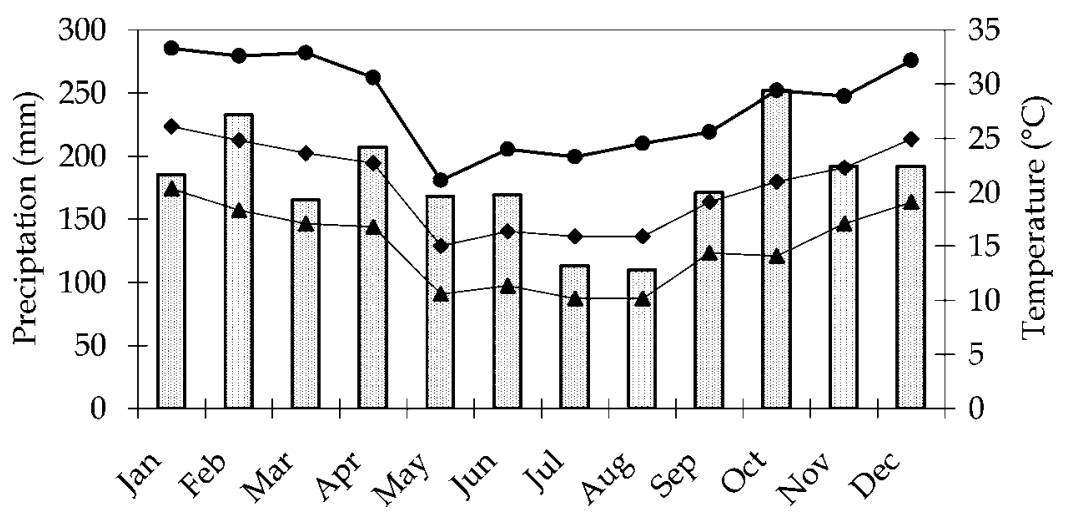

Figure 2. Climatic diagram of San Rafael National Park. Bars represent the average rainfall for each month from 1981 to 2003 (data obtained at Nueva Gambach, coordinates $26^{\circ} 38^{\prime} 15^{\prime \prime}$, $55^{\circ} 39^{\prime} 40^{\prime \prime} \mathrm{W}$; data provided by Pro Cosara). Lines are the maximum, mean and minimum temperatures for each month in 2004 (data from Estación Encarnación, Dirección de Meteorología e Hidrología).

vegetation. In low-lying areas the soil is waterlogged, and plant species such as Canna sp. and Ludwigia spp. predominate. In the higher areas, bushes of the family Myrtaceae are common, along with Asteraceae, Melastomataceae, Liliaceae, Rubiaceae and Convolvulaceae. Many grassland and wetland areas within San Rafael have been converted to agriculture or are used for cattle-ranching (see below), and are frequently affected by fires.

\section{Water}

Water includes rivers, streams, and ponds and channels created by dams and soil extraction. An artificial lagoon created by a dam in Nueva Gambach (see below) has promoted aquatic vegetation that attracts some bird species infrequently observed in the study area. This lagoon could be considered an 'anthropogenic area', or also a 'wetland', but is here considered as a 'water' habitat as many of the bird species are shared with natural bodies of water in the area.

\section{Anthropogenic areas}

Anthropogenic areas of the reserve are where human activity has changed the natural vegetation and landscape to agricultural land (including rice fields), cattle pastures, plantation of exotic trees, and urban areas ( $12 \%$ of the reserve).

\section{Study locations and methods}

A brief description of each study site is provided in Table 1 . Locations of these areas are shown in Figure 3 .

Surveys were carried out using standard methods: diurnal and nocturnal observations of birds in each habitat expressed as number of birds recorded per day. An estimate of relative abundance was derived for each species (see Appendix in Supplementary materials). Mist-netting by Lowen et al. (1996b) and Madroño et al. (1997a) provided additional information. Point counts by A.E. in a forest plot in Nueva Gambach during 2004-2005 provided some additional information as well, but these results will be presented in greater detail in a separate paper. Tape-recording and voice playbacks were used to help identify some species. 
Table 1 . Details of the locations surveyed in San Rafael National Park.

\begin{tabular}{|c|c|c|c|c|c|}
\hline Locality & Area $\left(\mathrm{km}^{2}\right)$ & Status & Habitat & Field surveys & Authors \\
\hline \multirow[t]{4}{*}{$\begin{array}{l}\text { Nueva } \\
\text { Gambach }\end{array}$} & \multirow[t]{4}{*}{$4 \cdot 4$} & \multirow[t]{4}{*}{ un } & \multirow[t]{4}{*}{$\begin{array}{l}\mathrm{F}, \mathrm{E}, \mathrm{S}, \mathrm{W} \\
\mathrm{Aq} \text {, aа }\end{array}$} & $\begin{array}{l}\text { Apr, Jun, } \\
\text { Nov } 1997 \text { (7) }\end{array}$ & 8 \\
\hline & & & & $\begin{array}{l}7 \text { visits during } \\
2000-2002(21)\end{array}$ & GP \\
\hline & & & & $\begin{array}{l}\text { Sporadically } \\
2003-2006(56)\end{array}$ & 1 \\
\hline & & & & $\begin{array}{l}\text { Feb, Mar } 2006 \\
(30)\end{array}$ & PS \\
\hline Arroyo Yhú & 11.4 & un & $\mathrm{F}, \mathrm{E}, \mathrm{S}$, аa & Jul 1995 (6) & Lw \\
\hline \multirow[t]{2}{*}{ San Pedro Mi } & \multirow[t]{2}{*}{31.64} & \multirow[t]{2}{*}{ un } & \multirow[t]{2}{*}{$\mathrm{G}, \mathrm{W}, \mathrm{F}, \mathrm{E}, \mathrm{S}, \mathrm{Aq}$, aa } & $\begin{array}{l}5 \text { visits during } \\
2000-2002(20)\end{array}$ & GP \\
\hline & & & & Dec 2003 (12) & 1 \\
\hline \multirow[t]{4}{*}{ Parabel } & \multirow[t]{4}{*}{14.22} & \multirow[t]{4}{*}{ un } & \multirow[t]{4}{*}{$F, E$, aa } & Nov 1996 (15) & $\mathrm{Ma}$ \\
\hline & & & & Dec 1996 (I) & 7,8 \\
\hline & & & & Apr, Nov 1997 (2) & 8 \\
\hline & & & & Oct $2000(9)$ & Zy \\
\hline Tebicuary River & $?$ & un & $\mathrm{F}, \mathrm{Aq}$ & Apr 1997 (4) & 8 \\
\hline \multirow[t]{5}{*}{ Kanguery } & \multirow{5}{*}{$25 \cdot 73$} & \multirow[t]{5}{*}{ pr } & \multirow[t]{5}{*}{$\mathrm{G}, \mathrm{W}, \mathrm{F}, \mathrm{E}, \mathrm{S}, \mathrm{Aq}$} & Oct 2001 (4) & $1,2,6$ \\
\hline & & & & Jun 2002 (2) & 6 \\
\hline & & & & Dec 2003 (1) & 1 \\
\hline & & & & Jul 2005 (2) & 5 \\
\hline & & & & Mar 2006 (2) & PS \\
\hline \multirow[t]{2}{*}{ Ka'aguy Rory } & \multirow[t]{2}{*}{23.67} & \multirow[t]{2}{*}{ un } & \multirow[t]{2}{*}{$\mathrm{G}, \mathrm{W}, \mathrm{F}, \mathrm{E}, \mathrm{S}, \mathrm{Aq}$, aa } & Oct, Nov 2001 (6) & $1,4,6$ \\
\hline & & & & Mar 2002 & 6 \\
\hline \multirow[t]{4}{*}{ San Isidro } & \multirow[t]{4}{*}{$35 \cdot 72$} & \multirow[t]{4}{*}{ un } & \multirow[t]{4}{*}{$\mathrm{G}, \mathrm{W}, \mathrm{F}, \mathrm{E}, \mathrm{S}, \mathrm{Aq}$, aa } & $\begin{array}{l}\text { Apr 1997, Nov } \\
1998 \text { (6) }\end{array}$ & 8 \\
\hline & & & & Oct $2000(8)$ & $\mathrm{Zy}$ \\
\hline & & & & Oct $2001(3)$ & 4 \\
\hline & & & & $\begin{array}{l}\text { Dec 2001, Jan } \\
2002(5)\end{array}$ & 6 \\
\hline San Clemente & 42.35 & un & $\mathrm{G}, \mathrm{W}, \mathrm{F}, \mathrm{E}, \mathrm{S}, \mathrm{Aq}$, aа & Apr, Nov 2001 (5) & GP \\
\hline \multirow[t]{2}{*}{ Guyra Reta } & \multirow[t]{2}{*}{$35 \cdot 38$} & \multirow[t]{2}{*}{ pr } & \multirow[t]{2}{*}{$\mathrm{F}, \mathrm{E}, \mathrm{S}, \mathrm{G}, \mathrm{Aq}$} & Nov $2001(6)$ & 2 \\
\hline & & & & $\begin{array}{l}\text { Mar, Jun } 2003 \\
\text { (13) }\end{array}$ & GP \\
\hline Santa Inés & 45.06 & un & F, E, S & $\begin{array}{l}\text { Jun, Nov } 2001 \\
\text { (10) }\end{array}$ & $1,2,3,4,6$ \\
\hline Hrisuk & 50.39 & un & $\mathrm{F}, \mathrm{E}, \mathrm{S}$ & Nov 2001 (4) & $1,2,6$ \\
\hline \multirow[t]{2}{*}{ Ocampos } & \multirow[t]{2}{*}{45.17} & \multirow[t]{2}{*}{ un } & $\mathrm{F}, \mathrm{E}, \mathrm{S}$ & Oct 2001 (8) & 1,2 \\
\hline & & & & Jan 2002 (2) & 6 \\
\hline
\end{tabular}

Status: un, unprotected; pr, protected.

Habitats: F, forest; E, forest edge; S, scrub; G, grassland; W, wetland; Aq, water; aa, anthropogenic areas. Field surveys: months are given as the first three letters; intensity of field effort, expressed as days of fieldwork, is shown in parentheses.

Data source, publications or observers: Lw, Lowen et al. (1996b); Ma, Madroño et al. (1997a); Zy, K. Zyskowski et al. (unpubl. data); PS, Paul Smith's team; GP, Guyra Paraguay's team; 1, A.E.; 2, M.C.V.; 3 , A.B.; 4, R.F.; 5, H.D.C.; 6, J.K.; 7, R.P.C.; 8, A.M.

\section{Systematic list and species accounts}

Taxonomy and nomenclature follow the South America Checklist Committee (Remsen et al. Version: 5 March 2006). Global conservation status of the species follows BirdLife International (2006). Endemic species status follows Brooks et al. (1999) and Guyra Paraguay (2004), with the 


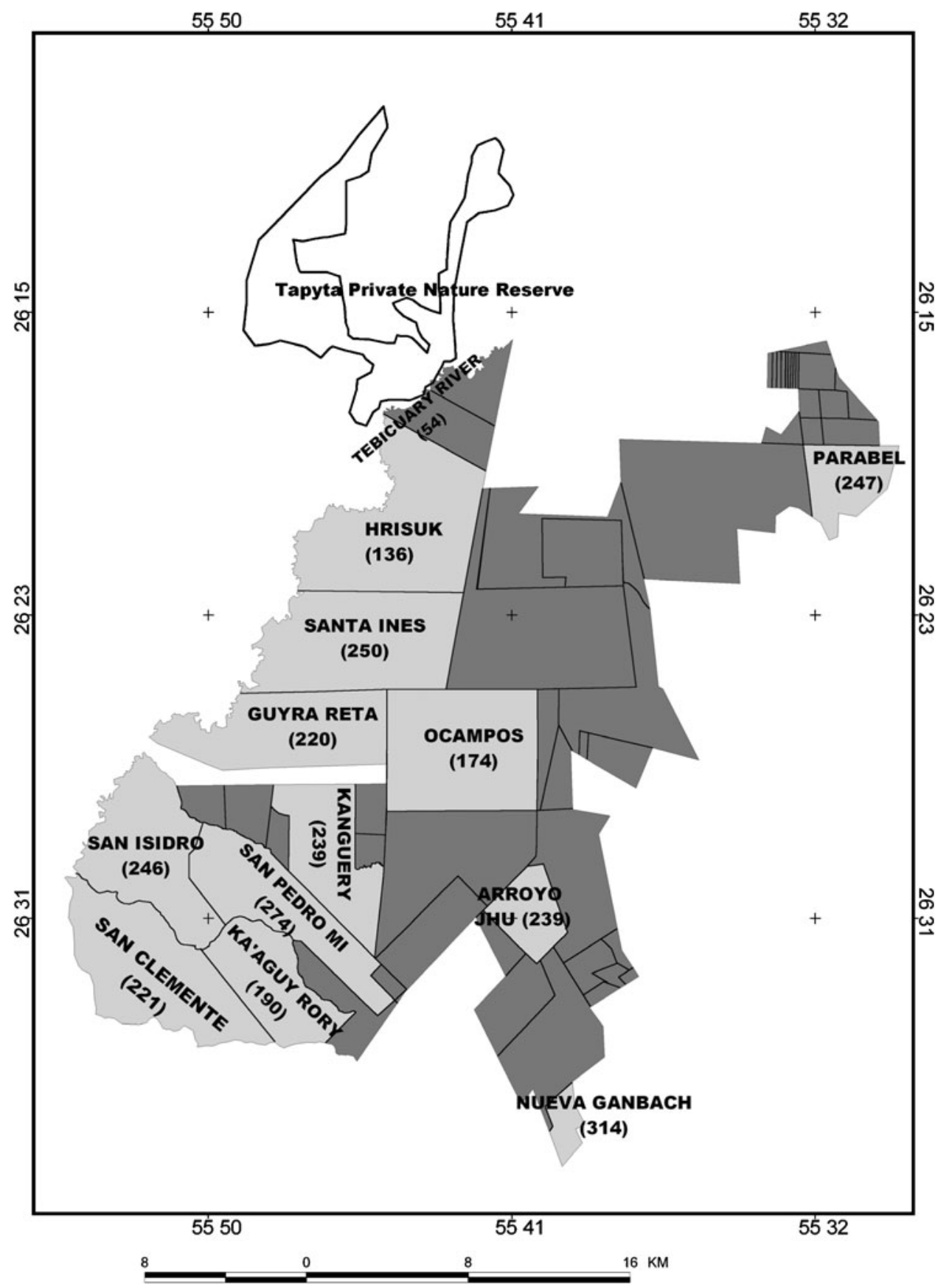

Figure 3. Ornithological survey locations in SRNP (light grey). Numbers in parentheses indicate the number of species found at each site. 
addition of Buff-bellied Puffbird Notharchus swainsoni and the exclusion of Red-ruffed Fruitcrow Pyroderus scutatus.

\section{Results}

\section{Species richness, seasonal patterns and habitat preferences}

A total of 405 bird species were found in SRNP (see Appendix in Supplementary materials). At least $192(47.4 \%)$ species are confirmed residents, and $79(19 \%)$ species are probably residents. Thirty-eight $(9 \%)$ species are migrants, of which seven are Nearctic migrants (breed in North America, found in SRNP during October-April), mostly sandpipers and swallows. Another six are southern austral migrants, mainly tyrant flycatchers, seen during May-September. Another 25 species are northern austral migrants, mainly hawks, tyrant flycatchers and seedeaters, seen October-April. Twenty-nine species ( $7 \%$ ) are considered vagrants, and most of these are rare or not previously recorded in the Alto Paraná ornithogeographic region (Guyra Paraguay 2004). A further 67 species $(16 \%)$ are extremely rare or poorly known in SRNP and their current status remains to be determined.

Habitats for each species are summarized in the Appendix (see Supplementary materials). It was beyond the scope of this study to identify microhabitats. However, it is worth noting that the Large-headed Flatbill Ramphotrigon megacephalum, Black-billed Scythebill Campylorhamphus falcularius, Bertoni's Antbird Drymophila rubricollis and Blackish-blue Seedeater Amaurospiza moesta were found in bamboo forest, and Greenish Tyrannulet Phyllomyias virescens, Riverbank Warbler Phaeothlypis rivularis and Sharp-tailed Streamcreeper Lochmias nematura in gallery forest.

A total of 230 species were recorded in forest habitats, of which 95 species appear to be restricted to this habitat ( 41 of these are endemic to the Atlantic Forest). The second highest species richness (154 species), was found in forest edge, with six species found only here. Anthropogenic areas were next (108 species, six of them not occurring in other habitats), followed by grasslands ( 93 species, of which 14 were found only here) and wetlands (46, with 8 only here). Finally, 49 species were recorded in water habitats, 24 of which were found only here.

\section{Threatened and near-threatened species accounts}

Twelve species are globally threatened: two Endangered (EN), 1o Vulnerable (VU). Another 16 species are Near Threatened (NT) (BirdLife International 2006).

\section{Greater Rhea Rhea americana (NT)}

Small flocks and occasional individuals were found in grasslands at three locations: San Pedro $\mathrm{Mi}$, San Isidro and San Clemente. Apparently more common in the past; estimates of 60 individuals were reported during the early 1970s, but by the end of the 1990s few individuals remained (R. Schultz verbally to A.M.). Habitat loss through frequent burning and conversion to pasture are local threats to the species. The Greater Rhea is a scarce species in the Alto Paraná ornithogeographic region (Guyra Paraguay 2004).

\section{Solitary Tinamou Tinamus solitarius (NT)}

This Atlantic Forest endemic is frequently recorded in San Rafael, especially during the breeding season (October-December) when individuals vocalize, usually at dusk. They are found in natural forest islands, edges of forest fragments, disturbed and primary forests. Hunting pressure may be the main threat to this species, suggested by its absence from areas of frequent hunting. For example, in Nueva Gambach many sobrados or mangrullo (hunting platforms) were found. 


\section{Black-fronted Piping-Guan Pipile jacutinga (EN)}

Reports from locals suggested that this species still occurred in the more mountainous, central part of SRNP (Lowen et al. 1996b), while it had been extirpated by hunting from the more accessible areas (Clay et al. 1999). First seen within the park in August 1998, it was suggested that the large forest block could maintain a larger population (Clay 2001).

\section{Crested Eagle Morphnus guianensis (NT)}

The only documented record in Paraguay, an eagle was captured near SRNP, and donated to the Itaipú Binacional Zoo (N. V. Perez pers. comm., MHNIB 872, Guyra Paraguay 2004). Yet large eagles were recorded on three occasions in San Rafael, once in San Clemente, another at Arroyo Yhú (omitted by Lowen et al. 1996b, cited by Madroño et al. 1997a), and in Parabel (Madroño et al. 1997a). It is possible that these reports are of Harpy Eagles (Harpia harpyja), and so the status of this species remains in doubt.

\section{Blue-winged Macaw Primolius maracana (NT)}

Reported by locals at Arroyo Yhú (Lowen et al. 1996b) and two groups of four birds were found in a 'biological corridor' (formed by the Arroyo Taya'y between Parque Nacional Caaguazú and SRNP) in December 1996 (E. Z. Esquivel pers. comm.). Thus, the species was considered likely in SRNP (Madroño et al. 1997a). Two pairs of birds were seen flying over the savanna of San Isidro in October 2001. Local people stated that the species was more abundant in the past.

\section{Vinaceous Parrot Amazona vinacea (VU)}

A local person reported seeing this species (Lowen et al. 1996b) and others reported a nesting pair in Nueva Gambach (in an Enterolobium sp. tree) around 1995, and two birds perched in a Chinaberry tree Melia azedarach plantation in January 2006. At San Pedro Mi, in December 2003, four birds, probably the Vinaceous Parrot, were seen, but were too far away for positive identification.

\section{Rusty-barred Owl Strix hylophila (NT)}

An individual in Nueva Gambach was seen in July 2000 and (presumably the same individual) has been seen there regularly since. The vocalizations of this individual were recorded, and it was photographed. A bird vocalizing $2 \mathrm{~km}$ to the north was probably another individual. Also found at Arroyo Yhú, where lone individuals were heard (Lowen et al. 1997).

\section{Sickle-winged Nightjar Eleothreptus anomalus (NT)}

Found at San Pedro Mi, an individual was seen flying over the grasslands in July 200o. One individual was also collected here by the team of the University of Kansas Natural History Museum (K. Zyskowski et al. unpubl. data).

\section{Saffron Toucanet Pteroglossus bailloni (NT)}

Often seen in pairs or small groups, most frequently in forest edges, and in degraded and primary forest. Small groups were feeding on fruits in Chinaberry Melia azedarach and White Mulberry Morus alba at Nueva Gambach. The largest group seen included 11 birds along with three Chestnut-eared Aracaris P. castanoti, in open secondary forest with abundant pioneer plants (such as Cecropia pachystachya) at San Pedro Mi. 


\section{Yellow-browed Woodpecker Piculus aurulentus (NT)}

Rarely recorded, usually only one individual per visit. This apparent rarity is likely due to the bird's cryptic behaviour and rare vocalizations. Yet, it was fairly common at Ocampos and Guyra Reta, where up to two individuals were frequently seen. This species is considered rare in the Atlantic Forest of Paraguay (Brooks et al. 1999, Lowen et al. 1995, Madroño et al. $1997 \mathrm{~b})$.

\section{Helmeted Woodpecker Dryocopus galeatus (VU)}

An Atlantic Forest endemic, this woodpecker is seldom recorded in SRNP, usually in the primary forest, but also in degraded forest and once, two birds were tape-recorded in a very narrow gallery forest at San Isidro. Since gallery forest is probably marginal habitat for this species, it is probably more common in more forested areas of the Park.

\section{White-browed Foliage-gleaner Anabacerthia amaurotis (NT)}

The only records for the reserve are an individual seen on 26 July and two on 30 July 1995 at Arroyo Yhú (Lowen et al 1996b, 1997a).

\section{Bearded Tachuri Polystictus pectoralis (NT)}

An austral migrant in Paraguay (Guyra Paraguay 2005), in SRNP this species was found a few times in grasslands at San Isidro, San Pedro Mi and Kanguery, even in heavily grazed areas. Most records are from the austral winter, with an individual seen in Kanguery during midFebruary 2006 (H. Cabral Beconi pers. comm. 2006).

\section{Southern Bristle-Tyrant Phylloscartes eximius (NT)}

A fairly common Atlantic Forest endemic in SRNP, usually found in pairs or in mixed-species flocks in the middle to understorey levels of the forest. Occurring in mature and degraded forests and in forest gaps, the species seems to prefer slightly open canopy and dense understorey. An individual in the forest mid-storey of San Pedro Mi was seen with a Mottle-cheeked Tyrannulet P. ventralis and a Greenish Tyrannulet Phyllomyias virescens, in a flowering Casearia sylvestris, with abundant insects that were captured in flight by the three birds.

\section{Sao Paulo Tyrannulet Phylloscartes paulistus (NT)}

Rare to uncommon and favouring mid-levels of the forest, this species was first reported in 1996 (Lowen et al. 1996b). Birds were seen in mixed-species flocks, more usually in primary forest, but once at the edge of a natural forest island in San Clemente.

\section{Bay-ringed Tyrannulet Phylloscartes sylviolus (NT)}

Rarely recorded in primary forest at San Pedro Mi, Nueva Gambach, Arroyo Yhú and Parabel, and in the gallery forest of the Tebicuary River.

\section{Sharp-tailed Tyrant Culicivora caudacuta (VU)}

Uncommon in grasslands in SRNP south-west, usually found in partially inundated tall grasslands $\left(>_{1} \mathrm{~m}\right)$. SRNP probably supports a stable and relatively sizeable population. 


\section{Russet-winged Spadebill Platyrinchus leucoryphus (VU)}

Fairly common in Parabel, where seven birds were found along $\sim_{1.5} \mathrm{~km}$ of forest trail, and an eighth about $1.5 \mathrm{~km}$ distant (Madroño et al. 1997a). The first known nest for the species was also found here (Clay and Madroño 1997). Birds were typically found in the understorey ( $1-3 \mathrm{~m}$ ) of primary forest, and were usually detected by their song or single-note contact call. In Ocampos, at least three birds were found, at Nueva Gambach four territories were located in a forest plot of 100 ha, and in Kanguery one bird was seen in a disturbed forest with open understorey (the result of cattle-grazing within the forest). This species was found at Tapyta Private Nature Reserve (adjacent to SRNP), in March 1997 in an isolated forest island ( $<_{I}$ ha) also with an open understorey due to cattle grazing. These findings suggest that SRNP combined with the neighbouring Caaguazú National Park (see Madroño et al. 1997a, b) comprise an important population for the species.

\section{Cock-tailed Tyrant Alectrurus tricolor (VU)}

This species was regularly found in the grasslands of the south-west of the reserve. Typically, individuals and family groups, with adults and immature birds, are found in grasslands $\left(>_{1}\right.$ $\mathrm{m})$. At San Isidro, four displaying males and two females were seen on October 2001 in Andropogon sp. and other introduced grasses. At Kanguery, it was sometimes seen in recently burnt and grazed grasslands in June 2001, but was more common in the same areas in July 2005 and February 2006, when the grasslands had not been burnt or grazed for several years.

\section{Strange-tailed Tyrant Alectrurus risora (VU)}

Similar to the Cock-tailed Tyrant, this species was found in grasslands of the south-west of the reserve, though would appear to be rarer than its congener. A female and an immature male were seen on June 1997 at San Isidro. At San Clemente, a male in breeding plumage was seen in grasslands where Cock-tailed Tyrant was also present.

\section{Bare-throated Bellbird Procnias nudicollis (VU)}

This Atlantic Forest endemic species is rarely recorded at SRNP. Birds were seen in the canopy of primary and degraded forest.

\section{Creamy-bellied Gnatcatcher Polioptila lactea (NT)}

Fairly common in SRNP, usually in pairs or small groups of up to four individuals, and often in mixed-species flocks in the canopy of degraded and primary forest. Other species seen with Creamy-bellied Gnatcatcher were Rufous-browed Peppershrike Cyclarhis gujanensis, Guira Tanager Hemithraupis guira, Sirystes Sirystes sibilator and Chestnut-vented Conebill Conirostrum speciosum.

\section{Ochre-breasted Pipit Anthus nattereri (VU)}

Regularly recorded in the grasslands of the south-west of the reserve. It appears to prefer grasslands with short grass, often in previously grazed areas. At least four birds were seen displaying in rolling grasslands at San Pedro Mi and Kanguery in October 2001. At San Clemente, five birds were found on one apparent territory in April 2001. On occasions, birds rose to $40-50 \mathrm{~m}$, then dropped suddenly, emitting a call after landing. 


\section{Marsh Seedeater Sporophila palustris (EN)}

This Mesopotamian Grasslands endemic has mostly been seen in Paraguay during its southward migration in early to mid-November (Madroño and Esquivel 1997). In SRNP, the species was first found in the grasslands of San Pedro Mi on 24 October 2001, but recently has been seen on a regular basis in the grasslands of Kanguery, where up to three males per day were seen during February and March 2006, suggesting local breeding.

\section{Chestnut Seedeater Sporophila cinnamomea (VU)}

Another uncommon Mesopotamian Grasslands endemic in the grasslands of SRNP. Records are from San Isidro, Guyra Reta and Kanguery during mid-October to mid-February and, as with $S$. palustris, the first dates are likely pertain to southbound migrants, while the later dates may indicate local breeding.

\section{Blackish-blue Seedeater Amaurospiza moesta (NT)}

This Atlantic Forest endemic appears to be a bamboo specialist, and was fairly common in suitable habitat throughout SRNP.

\section{Saffron-cowled Blackbird Xanthopsar flavus (VU)}

A fairly common species in the wetlands and wet grasslands of SRNP. Up to 250 birds were seen roosting in a rice field and nearby flooded grassland at San Clemente in April 2001, and groups of 30 to 50 individuals were seen in San Isidro, Ka'aguy Rory and Kanguery. Flocks were often with other Icteridae species (Unicolored Blackbird Agelasticus cyanopus, Yellow-rumped Marshbird Pseudoleistes guirahuro and Chopi Blackbird Gnorimopsar chopi). San Rafael probably contains at least 250 birds, and the species is likely to breed locally in the shallow marshes in the south-west of the reserve. The San Rafael population is believed to be continuous with other populations found further downstream in the Río Tebicuary basin (Fraga 2005).

\section{Green-throated Euphonia Euphonia chalybea (NT)}

Only reported by Lowen et al. (1996b), who considered it to be fairly common, with 28 sightings in Arroyo Yhú during 26-31 July 1995. Up to 11 birds were seen daily in seven distinct areas, but most were pairs or singing males (Lowen et al. 1997).

\section{Discussion}

\section{Avian diversity}

A total of 405 species of bird have now been reliably recorded in San Rafael National Park, a total representing $>57 \%$ of all species documented for Paraguay (Guyra Paraguay 2005). This is an increase of 112 species for SRNP from the previous published inventory (Madroño et al. 1997a). Only one other location in Paraguay has similar species richness: the Reserva Natural del Bosque Mbaracayú in the Department of Canindeyú. That reserve $\left(644 \mathrm{~km}^{2}\right)$ includes both Atlantic Forest and Cerrado habitats, and is undoubtedly the most studied in Paraguay in the past 20 years. To date, Mbaracayú contains at least 409 species (del Castillo et al. 2003).

San Rafael has the greatest known diversity of Atlantic Forest endemic bird species in Paraguay. Of the 79 Atlantic Forest endemics recorded, 70 (89\%) occur in SRNP (Guyra Paraguay 2004). Caaguazú National Park (Dept. Caazapá) and Estancia Itabó (Dept. Canindeyú) both have 66 endemics and Mbaracayú has 62 (Guyra Paraguay Biodiversity Database 2006). 
San Rafael is potentially an important location for endemics, but sampling effort should be standardized to clarify this possibility, perhaps by the use of species accumulation curves.

San Rafael and Mbaracayú both have notable avian diversity when compared with Atlantic Forests in Brazil. In the Tibagi River Basin (TRB, 24,530 km²), in the state of Paraná, in southern Brazil, 476 species were found (Anjos et al. 1997). That area is more than 30 times larger than San Rafael, though the mosaic of habitat types at each site appears to be similar. Considering particular habitats for comparisons, species richness in forest habitats is similar for the two sites, with 235 species recorded at TRB and 230 in SRNP. However, at TRB a greater diversity of species was recorded in forest edge and scrub (217 and 180 respectively, compared with 154 and 68 species in San Rafael). On the other hand, more grassland species occur at SRNP (93) compared with TRB (65). Within TRB the authors also identified local species richness: 273 species in Mata dos Godoy State Park $\left(6.5 \mathrm{~km}^{2}\right), 298$ in Varanal $\left(10 \mathrm{~km}^{2}\right)$ and 302 in Santa Rita Farm $\left(20 \mathrm{~km}^{2}\right)$. These totals are also similar to those for local species diversity within San Rafael: 274 species in San Pedro Mi $\left(32 \mathrm{~km}^{2}\right), 250$ in Santa Inés $\left(45.06 \mathrm{~km}^{2}\right)$ and 314 in Nueva Gambach $\left(4.4 \mathrm{~km}^{2}\right)$.

At the Iguassu National Park (Parque Nacional do Iguaçu), an area of $1,850 \mathrm{~km}^{2}$, only 335 species were recorded (Straube et al. 2004). In the Saibadela area of Parque Estadual Intervales $\left(380 \mathrm{~km}^{2}\right)$, south-east Brazil, during an intensive 2 year observational study, 234 species were found and at least 355 species were considered to occur here (Aleixo and Galetti 1997). In the Sooretama Biological Reserve $\left(240 \mathrm{~km}^{2}\right)$, in the state of Espirito Santo, 286 species were reported and in Itatiaia National Park $\left(300 \mathrm{~km}^{2}\right)$, in the state of Rio de Janeiro and Minas Gerais, 251 species were found (Parker and Goerck 1997). On Santa Catarina Island $\left(425 \mathrm{~km}^{2}\right)$, in the state of Santa Catarina, 269 species occur (Naka et al. 2002). San Rafael surpasses all in terms of overall species diversity, yet this is probably an artefact of differing levels of field effort. Therefore, we would suggest that SRNP is at least as diverse as any of these other, better known sites.

A more meaningful assessment of the global importance of San Rafael comes from the many threatened, near-threatened and Atlantic Forest endemic species, especially compared with those for Important Bird Areas (IBAs) in Brazil (as published in Bencke et al. 2006; Table 2). Many Brazilian IBAs include a larger altitudinal gradient and greater area than SRNP while containing a similar number of threatened and endemic species. Thus, we assert that San Rafael is as important for both avian diversity and threatened species as any other location in South America.

\section{Threats present and future}

Since its creation as an 'Area Reserved for National Park' in 1992, San Rafael has received very limited protection either on the ground or on paper, and remains divided among more than $4 \mathrm{O}$ private owners. Its exact legal status is still being debated. Originally created through the national protected areas law (SINASIP 352/94), it was reclassified in 2002 to a lower its protection category to 'Managed Resources Reserve', and 3 years later was reassigned to its former status of 'Area Reserved for National Park'.

Fragmentation of the Atlantic Forest is one of the main threats to the long-term conservation of its avifauna. Although SRNP is one of the two largest fragments of Atlantic Forest remaining in Paraguay, it is almost completely isolated, with only two narrow "biological corridors" linking it to the Caaguazú National Park (Parque Nacional Caaguazú) to the north. Clearing of forest patches continues unabated in the vicinity of the reserve (mainly for soy cultivation), and most grasslands in and near its boundaries are still used for cattle grazing, and suffer from frequent burns. Many have also been converted to pastures of exotic grasses. Illegal logging and hunting also continue within the reserve, though a vigilance programme by rangers of the NGO Pro Cosara in the last 5 years has helped to reduce these threats.

In recent years, fires have become an important threat to both the grasslands and forests of SRNP, and in particular to the important populations of globally threatened species such as Cock-tailed Tyrant, Saffron-cowled Blackbird, Ochre-breasted Pipit and Marsh Seedeater. For 
Table 2. Comparison of Threatened (T), Near Threatened (NT) and Atlantic Forest endemic (ATL) bird species between select Important Bird Areas (IBAs) in Brazil and Paraguay.

\begin{tabular}{|c|c|c|c|c|c|c|}
\hline IBAs & Biome & Area $\left(\mathrm{km}^{2}\right)$ & $\begin{array}{l}\text { Altitude } \\
(\mathrm{m})\end{array}$ & $\mathrm{T}$ & NT & ATL \\
\hline \multicolumn{7}{|l|}{ Paraná } \\
\hline Guaraqueçaba/Jacupiranga/Cananéia & ATL & 5,000 & $0-1,500$ & 17 & 27 & 108 \\
\hline Campos Gerais do Paraná & ATL, CE & $>60$ & $900-1,100$ & 9 & 17 & 73 \\
\hline Serra do Marumbí & ATL & 660 & $200-1,539$ & 7 & 28 & 117 \\
\hline APA de Guaratuba & ATL & 1,300 & $0-1,502$ & 13 & 23 & 110 \\
\hline Parque Nacional do Iguaçu & ATL & 1,865 & $200-600$ & 6 & 14 & 73 \\
\hline \multicolumn{7}{|l|}{ Río Grande do Sul } \\
\hline Região dos Aparados da Serra & ATL & 1,500 & $40-1,500$ & 10 & 20 & 87 \\
\hline Parque Estadual do Turvo & ATL & 174 & $100-400$ & 2 & 10 & 67 \\
\hline $\begin{array}{l}\text { Campos do Planalto das Araucárias } \\
\text { São Paulo }\end{array}$ & ATL & 8,500 & $900-1,450$ & 6 & 10 & 31 \\
\hline $\begin{array}{l}\text { Parque Estadual da Serra do Mar (entre } \\
\text { Caraguatatuba e Picinguaba) }\end{array}$ & ATL & 850 & $0-1,300$ & 13 & 25 & 109 \\
\hline Maciço Florestal de Paranapiacaba & ATL & 1,400 & $20-1,095$ & 14 & 29 & 121 \\
\hline Estaçao Ecológica de Juréia-Itatins & ATL & 800 & $0-1,300$ & 12 & 24 & 106 \\
\hline $\begin{array}{l}\text { Parque Estadual da Serra do Mar (entre } \\
\text { Santos e São Sebastião) }\end{array}$ & ATL & 1,100 & $100-1,200$ & 8 & 21 & 95 \\
\hline $\begin{array}{l}\text { Parque Estadual de Ilhabela } \\
\text { Río de Janeiro }\end{array}$ & ATL & 270 & $0-1,379$ & 5 & 12 & 66 \\
\hline Serra da Bocaina/Paraty/Angra dos Reis & ATL & 1,500 & $0-2,200$ & 13 & 29 & 123 \\
\hline Parque Nacional de Itatiaia & ATL & 300 & $650-2,791$ & 8 & 28 & 116 \\
\hline Serra dos Órgãos & ATL & 160 & $190-2,263$ & 8 & 20 & 104 \\
\hline Serra do Tinguá & ATL & 280 & $40-1,600$ & 9 & 21 & 97 \\
\hline Maciços da Tijuca e Pedra Branca & ATL & 157 & $80-1,024$ & 6 & 10 & 68 \\
\hline \multicolumn{7}{|l|}{ Paraguay } \\
\hline San Rafael National Park & ATL, MES & 730 & $100-500$ & 12 & 16 & 70 \\
\hline $\begin{array}{l}\text { Reserva Biológica Natural del Bosque de } \\
\text { Mbaracayú }\end{array}$ & ATL, CE & 644 & $140-450$ & 14 & 16 & 62 \\
\hline
\end{tabular}

Biomes: ATL, Atlantic Forest; CE, Cerrado; MES, Mesopotamian Grasslands.

example, intense fires in March 2005 burnt more than 1,060 ha of grasslands and 2,800 ha of forest within the reserve boundaries. These fires were deliberately set by local people to clear the land for agriculture.

One of the greatest recent achievements in terms of conservation in SRNP was the purchase of almost 6,00o ha of forest and grasslands for conservation by the Alliance for conservation of San Rafael (Guyra Paraguay, Pro Cosara and three other NGOs). Even so, the consolidation of the entire $748 \mathrm{~km}^{2}$ of the reserve must be considered an urgent priority for conservation in Paraguay, especially considering the status of San Rafael as the last retreat in the country for viable populations of many threatened and endemic species.

Increasing the numbers of forest rangers, and locating them strategically in the reserve, are necessary first steps to consolidate the area. Recently, the addition of four rangers (ringing the total to nine) and the establishment of a ranger post in Kanguery has resulted in a reduction in the number and frequency of fires, and an increase in the numbers of threatened grassland species being reported in the area.

Future surveys should focus on the more remote parts of SRNP, where additional species are likely to be discovered, and in which many threatened species, such as Black-fronted PipingGuan, may occur.

Attention should also be focused on the process of isolation of SRNP from nearby forest fragments. Further clearing of the small forest patches that surround SRNP should be avoided to 
maintain gene-flow between San Rafael and nearby reserves, such as the Tapyta Private Nature Reserve and the Caaguazú National Park (Parque Nacional Caaguazú).

Finally, we feel that this last stronghold of Atlantic Forest merits considerable attention from the conservation community. The problems of this reserve are a combination of all the usual conservation issues: forest fragmentation and isolation, habitat loss, agriculture and human population growth. Thus, this reserve could become an ideal example of how to preserve nature in the face of this combination of threats to conservation. If we can preserve this wonderful place, then we will learn an invaluable lesson in avian conservation.

\section{Acknowledgements}

A.E. is supported by a Spanish MAE-AECI 2003-2006 fellowship. Fernando González helped with the description of the vegetation. We would like to thank the rangers of SRNP and the NGO Pro Cosara for their help during fieldwork and for providing meteorological data of the area. Special thanks go to K. Zyskowski and Paul Smith for permission to use their data in the analyses and to Maximiliano Navarro, Eugenio Coconier, Sergio Villanueva and others not mentioned here who have also contributed to the knowledge of the avifauna of San Rafael. We acknowledge the role of Guyra Paraguay, who organized many of the ornithological surveys, and which were funded by American Bird Conservancy, Avina Foundation, New England Biolabs Foundation, NFWF, WWF-US, USAID Paraguay and USFWS. We would like to thank H. Cabral Beconi and Sonia Esquivel who prepared the maps. An early draft was much improved by an anonymous reviewer.

Supplementary material for this article can be found at journals.cambridge.org.

\section{References}

Aleixo, A. and Galetti, M. (1997) The conservation of the avifauna in a lowland Atlantic forest in south-east Brazil. Bird Conserv. Int. 7: 235-261.

Anjos, L. dos, Schuchmann, K. L. and Berndt, R. (1997) Avifaunal composition, species richness, and status in the Tibagi River Basin, Parana State, Southern Brazil. Ornitol. Neotrop. 8: 145-173.

Barboza, F., Pinazzo, J. and Fracchia, F. (1997) Bosque Atlántico Interior 1997. Mapa. Proyecto Sistema Ambiental de la Región Oriental (SARO). Asunción: Ministerio de Agricultura y Ganadería y World Wildlife Fund.

Bencke, G. A., Maurício, G. N., Develey, P. F., Goerck, J. M. orgs. (2006) Áreas Importantes para a Conservacao das Aves no Brasil. Part I: Estados do Domínio da Mata Atlántica. Sao Paulo: SAVE Brasil.

BirdLife International (2006) Threatened birds of the world 2006. On-line database: www.birdlife.org.
Brooks, T. M., Tobias, J. A. and Balmford, A. (1999) Deforestation and bird extinction in the Atlantic Forest. Anim. Conserv. 2: 211-222.

Cartes, J. L. (2000) Strategic private efforts for the conservation of Paraguayan biodiversity. European Tropical Forest Research Network News 31: 25-30.

Cartes, J. L. (2003) Brief history of conservation in the Interior Atlantic Forest. Pp. 269-287 in C. Galindo-Leal and I. Gusmão Cámara, eds. The Atlantic Forest of South America. London and Washington: Island Press.

CDC (1990) Áreas prioritarias para la conservación en la región oriental del Paraguay. Asunción: Centro de Datos para la Conservación.

Clay, R. P. (2001) The status and conservation of Cracids in Paraguay. Pp. 124-138 in D. M. Brooks and F. Gonzalez-G, eds. Ecology and conservation of cracids in the new millennium. Houston, Texas (Misc. Publ. Houston Mus. Nat. Sci., No. 2). 
Clay, R. P. and Madroño N., A. (1997) The first reported nest and eggs of the Russet-winged Spadebill Platyrinchus leucoryphus. Cotinga 8: 83-85.

Clay, R. P., Madroño, N. A. and Lowen, J. C. (1999) A review of the status and ecology of the Black-fronted Piping-guan Pipile jacutinga in Paraguay. Pp. 14-25 in D. M. Brooks, A. J. Begazo and F. Olmos, eds. Biology and conservation of the Piping-guans (Pipile). Houston: CSG (Spec. Publ. CSG No. I).

del Castillo, H., Clay, R., Madroño, A., Hosttetler, T. (2003) Lista de las aves de la Reserva Natural del Bosque de Mbaracayú. In J. Mazar Barnett, A. Madroño and D. Stanley. Aves de la Reserva Natural del Bosque Mbaracayú. Guía para la identificación de 200 especies. Asunción, Paraguay: Guyra Paraguay/ Fundación Moisés Bertoni/Fondo Francés para el Medio Ambiente Mundial.

DPNVS (1993) Plan estratégico del sistema nacional de areas silvestres protegidas del Paraguay (SINASIP). Asunción: Ministerio de Agricultura y Ganadería, Subsecretaría de Estado de Recursos Naturales y Medio Ambiente, Dirección de Parques Nacionales y Vida Silvestre.

Fraga, R. M. (2005) Behavior, ecology and social organization of Saffron-cowled Blackbirds (Xanthopsar flavus). Ornitol. Neotrop. 16: 15-29.

Guyra Paraguay (2004) Lista comentada de las aves del Paraguay. Annotated checklist of the Birds of Paraguay. Asunción, Paraguay: Guyra Paraguay.

Guyra Paraguay (2005) Atlas de las aves del Paraguay. Asunción, Paraguay: Guyra Paraguay.

Guyra Paraguay Biodiversity database on birds of Paraguay. Updated March 2006 (ongoing database).

Hayes, F. E. (1995) Status, distribution and biogeography of the birds of Paraguay. New York: American Birding Association (Monogr. Field Ornithol. I).

Keel, S., Gentry, L. and Spinzi, L. (1993) Using vegetation analysis to facilitate the selection of conservation sites in eastern Paraguay. Conserv. Biol. 7: 66-75.

Lowen, J. C., Clay, R. P., Brooks, T. M., Esquivel, E. Z., Bartrina, L., Barnes, R.,
Butchart, S. H. M. and Etcheverry, N. I. (1995) Bird conservation in the Paraguayan Atlantic Forest. Cotinga 4: 58-64.

Lowen, J. C., Bartrina, L., Brooks, T. M., Clay, R. P. and Tobias, J. (1996a) Project Yacutinga '95: bird surveys and conservation priorities in eastern Paraguay. Cotinga 5: 14-17.

Lowen, J. C., Bartrina, L., Clay, R. P. and Tobias, J. A. (1996b) Biological surveys and conservation priorities in eastern Paraguay. Cambridge, U.K.: CSB Conservation Publications.

Lowen, J. C., Clay, R. P., Mazar Barnett, J., Madroño, N. A., Pearman, M., López Lanús, B., Tobias, J. A., Liley, D. C., Brooks, T. M., Esquivel, E. Z. and Reid, J. M. (1997) New and noteworthy observations on the Paraguayan avifauna. Bull. Brit. Ornithol. Club 117: 275-293.

Madroño, N. A. and Esquivel, E. Z. (1995) Reserva Natural del Bosque de Mbaracayú: su importancia en la conservación de aves amenazadas, cuasi-amenazadas y endémicas del Bosque Atlántico del Interior. Cotinga 4: 52-57.

Madroño, N. A. and Esquivel, E. Z. (1997) Noteworthy records and range extensions of some birds from the Reserva Natural del Bosque Mbaracayú (Mbaracayú Forest Nature Reserve), Departamento de Canindeyú, Paraguay. Bull. Brit. Ornithol. Club 117: 166-176.

Madroño, N. A., Clay, R. P., Robbins, M. B., Rice, N. H., Faucett, R. C. and Lowen, J. C. (1997a) An avifaunal survey of the vanishing interior Atlantic forest of San Rafael National Park, Departments Itapúa/ Caazapá, Paraguay. Cotinga 7: 45-53.

Madroño, N. A., Robbins, M. B. and Zyskowski, K. (1997b) Contribución al conocimiento ornitológico del Bosque Atlántico interior del Paraguay: Parque Nacional Caaguazú, Caazapá. Cotinga 7: 54-6o.

Mittermeier, R. A., Fonseca, G. Da, Rylands, A. B. and Mittermeier, C. G. (1999) La Mata Atlántica. Pp. 137-144 in R. A. Mittermeier, N. Myers and C. G. Mittermeier, eds. Biodiversidad amenazada. Las ecorregiones terrestres prioritarias del Mundo. Mexico: Cemex - Conservación Internacional.

Myers, N., Mittermeier, R. A., Mittermeier, C. G., da Fonseca, G. A. B. and Kent, J. 
(2000) Biodiversity hotspots for conservation priorities. Nature 403: 853-858.

Naka, L. N., Rodrigues, M., Roos, A. L. and Azevedo, M. A. G. (2002) Bird conservation on Santa Catarina Island, Southern Brazil. Bird Conserv. Int. 12: 123-150.

Parker, T. A. III and Goerck, J. M. (1997) The importance of national parks and biological reserves to bird conservation in the Atlantic Forest Region of Brazil. Ornithol. Monogr. 48: 527-541.

Remsen, J. V. Jr, Jaramillo, A., Nores, M., Pacheco, J. F., Robbins, M. B., Schulenberg, T. S., Stiles, F. G., da Silva, J. M. C., Stotz,
D. F. and Zimmer, K. J. A classification of the bird species of South America. American Ornithologists' Union. http:// www.museum.lsu.edu/ $\sim$ Remsen/SACC Baseline.html (Version 5 March 2006). Stattersfield, A. J., Crosby, M. J., Long, A. J. and Wege, D. C. (1998) Endemic bird areas of the world. Priorities for biodiversity conservation. Cambridge, U.K.: BirdLife International. Straube, F. C., Urben-Filho, A. and Candido Jr J. F. (2004) Novas informações sobre a avifauna do Parque Nacional do Iguaçu (Paraná). Atualidades Ornitológicas 120: 10-28.

\section{ALBERTO ESQUIVEL M.}

Estación Ecológica de San Rafael (ECOSARA), Asociación Pro Cordillera San Rafael (Pro Cosara), Sitio Yatai, Alto Vera, Correo Postal Hohenau 2, Itapuá - Paraguay.

\section{SALVADOR J. PERIS*}

Departamento de Zoología, Facultad de Biología, Universidad de Salamanca, Campus Miguel de Unamuno s/n, 37071 Salamanca, Spain.

\section{ROSENDO FRAGA}

CICYTTP - CONICET, Matteri y España, 3105 Diamante, Entre Ríos, Argentina.

\section{ROBERT P. CLAY}

Americas Secretariat/Secretariado, BirdLife International, Vicente Cárdenas E5-75 y Japón, 3er. Piso. C.P. 17-17-717, Quito, Ecuador.

\section{ALEJANDRO BODRATI}

Proyecto Selva de Pino Paraná, Fundación de Historia Natural Félix de Azara, Departamento de Ciencias Naturales y Antropologia, CEBBAD - Universidad Maimónides, Valentín Virasoro 732, C1405BDB Buenos Aires, Argentina.

\section{HUGO DEL CASTILLO, JUAN KLAVINS}

Asociación Guyra Paraguay, Cnel. Rafael Franco $N^{\circ} 381 \mathrm{cl}$ Leandro Prieto, Asunción, Paraguay.

\section{MYRIAM C. VELÁZQUEZ}

Fundación Moisés Bertoni, Procer Arguello N 208 cl Mcal. López, Asunción, Paraguay.

\section{ALBERTO MADROÑO}

Sociedad Española de Ornitología SEO/BirdLife, C/ Melquíades Biencinto 34, 28053 Madrid, Spain.

*Author for correspondence; e-mail: betoesquivelmat@yahoo.com 